\title{
THE HOURLY DISTRIBUTION OF MOTH SPECIES CAUGHT BY A LIGHT-TRAP
}

\author{
L. NOWINSZKY ${ }^{*}{ }^{1}$ - Z. MÉSZÁROS ${ }^{2}$ - J. PUSKÁS ${ }^{1}$ \\ ${ }^{1}$ Berzsenyi Dániel College, H-9701 Szombathely, Károlyi Gáspár Square 4, Hungary \\ (phone: +36-94-504-357) \\ ${ }^{2}$ Corvinus University of Budapest, Department of Entomology, H-1118 Budapest, Ménesi Str. \\ 44, Hungary \\ e-mail:nlaszlo@bdtf.hu \\ (Received $31^{\text {th }}$ May 2006; accepted $15^{\text {th }}$ Apr 2007 )
}

\begin{abstract}
The present study discusses the hourly distributions of Macolepidoptera and Microlepidoptera species caught by a light-trap. The fractional type mercury vapour $(125 \mathrm{~W})$ light-trap had been operated by Mészáros, at Julianna-farm of the Plant Protection Institute between 1976 August and 1979 July. This trap was not in operation every night in this period, only periodically. It was in work during 57 nights in total. We summarized all caught specimen of all species hourly. In this way, we examined data of 66 species. We calculated percentages from hourly-totalized specimen number. We made a comparison between nightly distributions in caught species activity and Tshernishev's activity types.
\end{abstract}

Keywords: : Lepidoptera, fractional catching, flying activity

\section{Introduction and survey of literature}

The question of the distribution of the catch by light-trap in the course of a night has been a subject of research for several decades. Williams [1] used a fractionating lighttrap in four years of examining flight activity as it was changing over the night. A glassreplacing device separated the catch into eight groups. Always adapted to the time of sunset and sunrise, the duration of light trapping varied. Accordingly, the periods of the individual phase of collecting also showed differences, but the fourth period always ended at midnight.

His sum total has revealed that he caught the largest number of insects in the first phase and the smallest in the seventh. Lepidoptera species flew to light in the highest number in the second, fifth and eight phases. However, the time of flight activity of nocturnal insects varies by species (Steward and Lam, [2], Hitchen et al., [3]).

There is significant difference among active flight periods of species even from the same family, according to the results of examinations (Wallner et al., [4]) in the near eastern part of Russia. According to these examinations the highest activity periods of moths are the following: gypsy moth (Lymantria dispar L.) between 11 p.m. and 1 a.m. The black arches (Lymantria monacha L.) between 3 a.m. and 5 a.m. and rosy gypsy moth (Lymantria mathura Moore) between 1 a.m. and 3 a.m. Ambrus and Csóka [5] determined that there is a difference in the light-trap periods of the two sexes of pine moth (Dendrolimus pini L.). The males fly to the light also during late night but females rather in the first part of the night to 22 and 23 hours. There is a relationship between activity and flight to light.

Tshernishev [6] claims that the flight activity of each species follows a special daily rhythm that usually corresponds to the time of flying to light. From this point of view, he establishes four basic types of insects: 
- Flight of short duration tied exclusively to twilight, can never be observed by night (most Ephemeroptera, Corixida, Coleoptera, Diptera and Hepialida species),

- Species of a flight of longer duration. They start their flight later, reaching the peak in the evening. Some species fly all night (Trichoptera, Chironomida and a few eastAfrican Ephemeroptera species),

- Intensive flight from sunset to close on sunrise, not letting up during the night (Tripuloidea and Ephemeroptera species),

- Typical night flight with a well discernible nocturnal peak (Ophionina, Lepidoptera, especially the species of Noctuidae and Brown chafer (Serica brunnea L.).

In the same work, the author lays down for a number of insect orders and for some significant species, the values of illumination expressed in lux characterizing the beginning and the peak of the activity. The activity of most Lepidoptera species increases from 0.01 lux to 0.001 lux but decreases by illumination below that value.

Járfás et al. made examinations in Hungary with fractional light-trap to determine the flight to the light of some harmful moths during night. They published the results in different years. We show these published results in Table 1.

In this present study, we show the flight activity of not only the significant harmful moths, but also the flight of those species, which can not be known in any publication in the Hungarian and international literature.

\section{Material and method}

A fractional type mercury vapour $(125 \mathrm{~W})$ light-trap was in work, operated by Mészáros, at Julianna-farm of the Plant Protection Institute between 1976 August and 1979 July. This trap was not in operation every night, but only periodically. It was in work during 57 nights. The working period was 12 hours in spring, summer and the beginning of autumn from 5 p.m. until 5 a.m., but from the second part of October between 4 p.m. and 4 a.m. (UT). Mészáros identified all Macrolepidoptera species and the harmful Microlepidoptera ones from the caught insect material. We used this data in this study.

We summarized hourly all caught specimen of all species. We did not examine later those species which number was 5 or less. In this way, we examined data of 66 species. We calculated percentages from the total hourly specimen number. We made comparison between nightly distributions in caught species activity and Tshernishev's activity types when the specimen number was high.

\section{Results}

The percentages of hourly caught specimen number of examined species are shown in Table 2. For each species, the total trapped individual number and the number of those nights when these species were caught by the light-trap is shown.

\section{Discussion}

The nightly activity of Macrolepidoptera species, except one, belongs to the 4th Tshernishev type. Types 1 and 2 do not occur. It is striking, although these species fly to 
the light during all night, light-traps did not catch before 7 p.m. in none of the months. Generally, the swarming peak can be found between 9 p.m. and midnight.

The activity types of Macrolepidoptera species belong to type 2 and 4 . The frequency is almost the same in these types. Type 3 is infrequent, and type 1 can not be found as well.

There are differences between Tshernishev's types and type 3 and 4, because we found 2-2 activity peaks in the first part of the night or rather during the whole night ( $3 \mathrm{a}$ and $4 \mathrm{a})$.

Table 2 shows those species, of which more than 5 individuals were caught, but their number was insufficient to determine nightly distribution. We also publish these results, because they prove that these species are active during the period.

Table 1. The hourly distribution (\%) of harmful moth species caught by light-trap according to Járfás et al.

\begin{tabular}{|l|c|c|c|c|c|c|c|c|c|c|c|}
\hline Species/hours & $\begin{array}{c}\mathbf{1 8 -} \\
\mathbf{1 9}\end{array}$ & $\begin{array}{c}\mathbf{1 9 -} \\
\mathbf{2 0}\end{array}$ & $\begin{array}{c}\mathbf{2 0}- \\
\mathbf{2 1}\end{array}$ & $\begin{array}{c}\mathbf{2 1}- \\
\mathbf{2 2}\end{array}$ & $\begin{array}{c}\mathbf{2 2 -} \\
\mathbf{2 3}\end{array}$ & $\begin{array}{c}\mathbf{2 3 -} \\
\mathbf{2 4}\end{array}$ & $\mathbf{0 - 1}$ & $\mathbf{1 - 2}$ & $\mathbf{2 - 3}$ & $\mathbf{3 - 4}$ & References \\
\hline $\begin{array}{l}\text { Hyponomeuta } \\
\text { spp. }\end{array}$ & 3,3 & 6,1 & 15,0 & 19,0 & 14,9 & 17,2 & 12,4 & 8,1 & 2,4 & 1,6 & Járfás [7] \\
\hline $\begin{array}{l}\text { Pandemis } \\
\text { dumetana } \text { Tr. }\end{array}$ & 5,5 & 19,3 & 23,8 & 16,4 & 8,9 & 6,7 & 5,3 & 5,1 & 6,1 & 2,9 & Járfás [7] \\
\hline $\begin{array}{l}\text { Pandemis } \\
\text { heparana } \\
\text { Schiff. }\end{array}$ & 19,4 & 14,4 & 17,1 & 14,7 & 14,5 & 7,2 & 5,1 & 3,5 & 1,6 & 2,5 & Járfás [7] \\
\hline $\begin{array}{l}\text { Pandemis } \\
\text { ribeana } \text { Hbn. }\end{array}$ & 8,8 & 6,0 & 17,6 & 23,5 & 6,0 & 8,8 & 14,7 & 8,8 & 2,9 & 2,9 & Járfás [7] \\
\hline $\begin{array}{l}\text { Adoxophyes } \\
\text { reticulana } \text { Hbn }\end{array}$ & 8,1 & 6,4 & 7,2 & 5,2 & 7,8 & 15,1 & 17,7 & 15,7 & 12,2 & 4,6 & Járfás [7] \\
\hline $\begin{array}{l}\text { Laspeyresia } \\
\text { pomonella } \text { L. }\end{array}$ & 5,3 & 8,9 & 15,6 & 14,0 & 14,5 & 14,2 & 11,1 & 8,2 & 4,6 & 3,6 & Járfás [9] \\
\hline $\begin{array}{l}\text { Ostrinia } \\
\text { nubilalis Hbn. }\end{array}$ & 6,3 & 8,4 & 14,6 & 16,3 & 14,1 & 11,0 & 10,3 & 9,2 & 6,2 & 3,6 & Járfás [8] \\
\hline $\begin{array}{l}\text { Loxostege } \\
\text { sticticalis } \text { L. }\end{array}$ & 4,0 & 8,6 & 10,0 & 15,0 & 10,9 & 12,2 & 12,0 & 10,3 & 8,0 & 9,0 & Járfás and \\
Viola [12]
\end{tabular}


Table 2. Light-trap catch (in \%) of the examined species during night (UT)

\begin{tabular}{|c|c|c|c|c|c|c|c|c|c|c|c|c|c|c|c|}
\hline Species & $16-17$ & $17-18$ & $18-19$ & $19-20$ & $20-21$ & $21-22$ & $22-23$ & 23-24 & $0-1$ & $1-2$ & $2-3$ & $3-4$ & $4-5$ & $\begin{array}{c}\text { Indi- } \\
\text { viduals }\end{array}$ & Nights \\
\hline $\begin{array}{l}\quad \text { Plutellidae } \\
\text { Plutella } \\
\text { maculipennis } \\
\text { Curt. (4) }\end{array}$ & & & & 15,0 & 18,0 & 19,0 & 25,0 & 5,0 & 5,0 & 6,0 & 1,0 & & & 262 & 24 \\
\hline $\begin{array}{l}\quad \text { Gelechiidae } \\
\text { Recurvaria } \\
\text { nanella } \mathrm{Hbn} .\end{array}$ & & & & & & 17,0 & 34,0 & & 17,0 & 34,0 & & & & 6 & \\
\hline $\begin{array}{l}\quad \text { Tortricidae } \\
\text { Tortrix viridana } \\
\text { L. (4) } \\
\text { Pandemis } \\
\text { heparana Schiff. } \\
\text { (4) } \\
\text { Pandemis } \\
\text { ribeana } \text { Hbn. (3) } \\
\text { Hedia } \\
\text { nubiferana Haw. } \\
(4) \\
\text { Spilonota } \\
\text { ocellana } \mathrm{F} . \text { (4) } \\
\text { Laspeyresia } \\
\text { pomonella } \mathrm{L} \text {. }\end{array}$ & & & $\begin{array}{l}0,4 \\
2,2 \\
14,3 \\
0,6\end{array}$ & $\begin{array}{l}4,5 \\
8,9 \\
9,5 \\
2,5 \\
14,3 \\
16,7\end{array}$ & $\begin{array}{l}25,6 \\
28,9 \\
14,3 \\
15,4 \\
35,7\end{array}$ & $\begin{array}{l}23,7 \\
33,3 \\
14,3 \\
14,8 \\
16,7\end{array}$ & $\begin{array}{c}21,1 \\
15,6 \\
9,5 \\
22,2 \\
28,6 \\
16,7\end{array}$ & $\begin{array}{c}11,7 \\
6,7 \\
14,3 \\
11,7 \\
7,1 \\
16,7\end{array}$ & $\begin{array}{c}7,1 \\
2,2 \\
9,5 \\
14,2 \\
7,1\end{array}$ & $\begin{array}{l}4,5 \\
2,2 \\
9,5 \\
11,7\end{array}$ & 0,8 & 16,7 & $\begin{array}{l}1,2 \\
7,1\end{array}$ & $\begin{array}{l}266 \\
45 \\
21 \\
162 \\
14 \\
6\end{array}$ & $\begin{array}{c}2 \\
10 \\
8 \\
7 \\
14 \\
2 \\
4\end{array}$ \\
\hline $\begin{array}{l}\quad \text { Pyralidae } \\
\text { Oncocera } \\
\text { semirubella } \\
\text { Scop. } \\
\text { Sitochroa } \\
\text { verticalis } \text { L. (4) } \\
\text { Microlepidoptera } \\
\text { spec. indet. }\end{array}$ & & 0,2 & 1,3 & $\begin{array}{l}6,7 \\
5,3\end{array}$ & $\begin{array}{l}13,3 \\
12,0\end{array}$ & $\begin{array}{c}16,7 \\
6,7 \\
14,0\end{array}$ & $\begin{array}{l}33,3 \\
40,0 \\
22,1\end{array}$ & $\begin{array}{l}16,7 \\
12,0\end{array}$ & 13,0 & $\begin{array}{l}16,7 \\
20,0 \\
11,6\end{array}$ & $\begin{array}{l}6,7 \\
6,8\end{array}$ & $\begin{array}{l}6,7 \\
1,7\end{array}$ & 0,2 & $\begin{array}{c}6 \\
15 \\
2802\end{array}$ & $\begin{array}{c}5 \\
7 \\
39\end{array}$ \\
\hline $\begin{array}{l}\quad \text { Drepanidae } \\
\text { Polyploca ridens } \\
\text { Hbn. (2) } \\
\text { Asphalia } \\
\text { ruficollis Schiff. } \\
\text { (2) } \\
\text { Drepana binaria } \\
\text { Hfn. (4) }\end{array}$ & & 7,1 & 50,0 & $\begin{array}{r}26,3 \\
19,0 \\
4,8\end{array}$ & $\begin{array}{l}34,2 \\
14,3 \\
14,3\end{array}$ & $\begin{array}{c}0,0 \\
2,4 \\
42,9\end{array}$ & $\begin{array}{c}7,9 \\
4,8 \\
23,8\end{array}$ & 2,6 & 9,5 & 5,3 & $\begin{array}{l}7,9 \\
2,4 \\
4,8\end{array}$ & & & $\begin{array}{l}38 \\
42 \\
21\end{array}$ & $\begin{array}{l}5 \\
4 \\
8\end{array}$ \\
\hline $\begin{array}{l}\quad \text { Geometridae } \\
\text { Chiasmia } \\
\text { clathrata } \text { L. (4) } \\
\text { Biston stratarius } \\
\text { Hfn. (2) } \\
\text { Apocheima } \\
\text { hispidaria } \\
\text { Schiff. (2) } \\
\text { Lycia hirtaria } \\
\text { Cl. (4) } \\
\text { Lycia zonaria } \\
\text { Schiff. } \\
\text { Biston betularia } \\
\text { L. } \\
\text { Erannis } \\
\text { marginaria } \text { Bkh. } \\
\text { Bapta temerata } \\
\text { Schiff. }\end{array}$ & & $\begin{array}{l}2,4 \\
4,4 \\
8,9 \\
12,5\end{array}$ & $\begin{array}{l}18,1 \\
40,0 \\
6,7\end{array}$ & $\begin{array}{r}32,1 \\
24,4 \\
4,4\end{array}$ & $\begin{array}{c}9,1 \\
22,1 \\
22,2\end{array}$ & $\begin{array}{l}22,7 \\
5,6 \\
4,4 \\
2,2\end{array}$ & $\begin{array}{l}31,8 \\
8,0 \\
2,2 \\
24,4 \\
62,5 \\
14,3 \\
33,3 \\
14,3\end{array}$ & $\begin{array}{l}28,6 \\
11,1 \\
14,3\end{array}$ & $\begin{array}{r}8,9 \\
12,5 \\
14,3 \\
11,1\end{array}$ & $\begin{array}{l}15,6 \\
12,5 \\
28,6\end{array}$ & $\begin{array}{l}9,1 \\
0,8 \\
2,2\end{array}$ & 4,4 & & $\begin{array}{l}22 \\
249 \\
45 \\
45 \\
8 \\
7 \\
9 \\
7\end{array}$ & $\begin{array}{l}13 \\
21 \\
8 \\
10 \\
3 \\
6 \\
5 \\
1\end{array}$ \\
\hline
\end{tabular}




\section{REFERENCES}

[1] Williams, C. B. (1935): The times of activity of certain nocturnal insects, chiefly Lepidoptera, as indicated by a light trap. - Trans. Roy. Soc. London. 83: 523-556.

[2] Steward, P. A., Lam, J. J. (1969): Hourly and seasonal collections of six harmful insects in traps equipped with blacklight lamps. - J. Econ. Ent. 62. 1: 100-103.

[3] Hitchen, J. M., Hitchen, E. T., Jackson, C. M., Meers, G. H. (1969): The flight times of some nocturnal moths. - Entomologist. 102: 80-85.

[4] Wallner, W. E., Humble, L. M., Levin, R. E., Baranchikov, Y. N., Cardé, R. T. (1995): Response of adult Lymantriid moths to illumination devices in the Russian Far East. - J. Econ. Entomol. 88. 2: 337-342.

[5] Ambrus, A., Csóka, Gy. (1989): Data from damage and living of pine lappet (Dendrolimus pini L.) (in Hungarian). - Az Erdő. 38. 5: 231-232.

[6] Tshernyshev, V. B. (1961): Time of fly of the insects into light (in Russian). - Zool. Zhurn. 40. 7: 1009-1018.

[7] Járfás, J. (1977): Light-trap results of harmful Tortricidae (in Hungarian). - Kertészeti Egyetem Közleményei. 41: 123-125.

[8] Járfás, J. (1978): The effectively of different light trapping methods in studying the flight activity of European corn borer (in Hungarian). - Növényvédelem. 14. 10: 494-498.

[9] Járfás, J. (1979): Forecasting of harmful moths by light-traps (in Hungarian). - PhD Thesis. Kecskemét. 127.

[10] Járfás, J., Szabó, E., Sohajda, I. (1975): Evaluation of meteorological factors influencing the signalization of Autographa gamma L. based on light-trap (in Hungarian). Kertészeti Egyetem Közleményei. 39: 167-175.

[11] Járfás, J., Viola, M. (1985): The activity and nutrition of the fall webworm moth (Hyphantria cunea Drury) (Lepidoptera: Arctiidae) I. (in Hungarian). - Kertészeti Egyetem Közleményei. 49: 175-182.

[12] Járfás, J., Viola, M. (1991): The results of the observations of special light-traps for meadow moths (Loxostege sticticalis L.) (in Hungarian). - Kertgazdaság. 4: 65-70. 